\title{
CORRELATION BETWEEN JOB ANALYSIS AND CORPORATE PERFORMANCE OF BUSINESS ORGANIZATIONS IN NIGERIA: A STUDY OF NIGER MILL PLC CALABAR
}

\author{
Ele Augustine Augustine ${ }^{1}$, Enya Francis Ejeje ${ }^{2}$, Dr. Okongo Nsor John ${ }^{3}$, \\ Eja Basil Richard ${ }^{4}$ and Mbam John Nwuguru ${ }^{5}$
}

${ }^{1}$ Department of Business Management, Faculty of Management Sciences, University of Calabar,
Calabar - Nigeria. P.M.B 1115. Email: elenoble2000@ yahoo.com; Phone No: 07069146719

${ }^{2}$ Department of Accounting, Faculty of Management Sciences, University of Calabar, Calabar Nigeria. P.M.B 1115. Email: enyafrancisejeje@gmail.com; PHONE NO: 08066935105.

${ }^{3}$ Department of Business Management, Faculty of Management Sciences, University of Calabar, Calabar-Nigeria. P.M.B 1115. Email: nsor_john@yahoo.com; Phone NO: 08038179681.

${ }^{4}$ Department of Banking And Finance, Faculty of Management Sciences, University of Calabar, Calabar- Nigeria. Email: ejabasil@yahoo.com; Phone No: 08037897970.

${ }^{5}$ Department of Business Management, Faculty of Management Sciences, Ebonyi State University, Abakaliki, Nigeria. Email: mbamj69@gmail.com; Tel: 08068061966.

Cite this article:

Ele A.A., Enya F.E., Okongo N.J., Eja B.R., Mbam J.N. (2021), Correlation Between Job Analysis and Corporate Performance of Business Organizations in Nigeria: A Study of Niger Mill Plc Calabar. International Journal of Entrepreneurship and Business Innovation 4(1), 6181. DOI: $10.52589 /$ IJEBIA53IJGYX.

\section{Manuscript History \\ Received: 9 Oct 2020 \\ Accepted: 27 Nov 2020 \\ Published: 19 June 2021}

Copyright $\odot 2020$ The Author(s). This is an Open Access article distributed under the terms of Creative Commons AttributionNonCommercial-NoDerivatives 4.0 International (CC BY-NC-ND 4.0 ), which permits anyone to share, use, reproduce and redistribute in any medium, provided the original author and source are credited.
ABSTRACT: This study focused on the correlation between job analysis and corporate performance of business organizations in Nigeria. The study adopted both descriptive surveys as well as correlational survey designs. The population of this research work was 400, the entire staff of Niger Mill Plc Calabar, Cross River State. The sample size was 200 respondents determined through Taro Yamane's formula of 1964. The data was collected using both primary and secondary sources. A structured questionnaire was used using a 4-point Likert scale of strongly agreed, agreed, strongly disagreed and disagreed. The study adopted the Pearson Product Moment of Correlation Coefficient to test the hypotheses and analyzed data at $0.05 \%$ significance. The study revealed that was a significant relationship existing between job analysis and corporate performances of business organizations in Nigeria. It was also discovered that significant relationships existed between job description, specification as well as job evaluation, and corporate performance of business organizations. It was recommended that the management of business organizations should incorporate a well-established job analysis programme into their human resource planning during recruitment and training of existing and prospective employees to boast its overall corporate performance continuously. Human resource managers should also endeavour to describe organizational jobs and specify the person who is to carry out the tasks with the basic knowledge, skills, competency, ability, and other job characteristics for the corporate performance to be enhanced steadily.

KEYWORDS: Job Analysis, Job Description, Job Specification, Job evaluation, and Corporate Performance. 


\section{INTRODUCTION}

Job analysis has grown in scope and application over the last few decades. It is an essential and rich source of information about jobs and jobholders. It is an essential and rich source of information about jobs and job holders that professionals and managers use to develop documents such as job descriptions, job specifications, and job evaluation as well as performance standards for improved corporate performance. These documents serve as the basis for human resource management in some related areas. Hence, human resource practices such as training and development, recruitment and selection strategies, performance appraisals, compensation, health as well as safety requirements are increasingly developed around the demands and characteristics of jobs to be clearly understood both by the job holders and the organizations.

Job analysis is a systematic process of studying, identifying, and collecting detailed information relating to the operations and responsibilities of a specific job that states the skills, knowledge, abilities, and other job characteristics needed for the job. Job analysis is widely recognized with its uses as organizational data collection technique for the determination of the nature of a job, such as job content, context, and requirements with the pertinent technical skills, competencies, knowledge, abilities and other job characteristics needed from employees and the prospective employees to perform their jobs more successfully (Ele, Makama \& Okongo, 2020). Job analysis is the orderly process of studying, identifying, collecting and setting out detail information concerning the content of jobs to provide the fundamental basis for a job description and data for recruitment, training, job evaluation, job specification, career planning, performance appraisal system, promotion and performance management for organizational performance to be accomplished more successfully (Ele, et al, 2020; Armstrong, 2009 ; 2012). Job analysis is a vital tool for effective human resource planning policy of any given organization either private or public (Ele, et al 2020). They further stated that job analysis is a fundamental internal strategy use by human resource managers, job analysts, professionals as well as practitioners in obtaining necessary or pertinent information about the jobs and the workers before or during selection for recruitment as well as training of existing and prospective employees in any given organization.

Job analysis concentrates on what job holders are expected to do and accomplish more successfully. It identifies the tasks job holders undertake and the results as well as outputs they are expected to produce. Job analysis defines the nature, context, content, and other characteristics of the job within the organization, and the behaviours that necessary are associated with performing those jobs (Ele, Umana, Inyang \& Eneh, 2019). Job analysis is one of the most important functions or activities of human resource management and can perform multi-functions such as job description, job specification, job evaluation, etc. Job analysis can offer a solution for most effective work organization or classification of work, improving ineffective processes of redesign work, planning training for introducing new employees into existing processes, or existing workers in new processes, establishes criteria assessment of employment effect, adequate and fair compensation, planning of employees' welfare throughout their careers (Stoilkovska \& Serafimovic, 2017; Ele, et al, 2020). It is an integral part of human resource planning during selection for recruitment and selection for training and development needs assessment (Ele, et al, 2020).

The issue of poor corporate performance and low productivity in the Niger Mills Plc has become a thing of great concern to the management of the firm as a result of a lack of proper 
analysis of jobs as the employees perform their tasks. Corporate performance is defined as the process of achieving the final results of which a particular organization has been established, for the sustainability of its goals and objectives over a given period (Ele, 2014). It is the total or entire final results of all the organizational activities or practices of job or jobs performed for its efficiency and effectiveness to be maintained and achieved in an organization. The corporate performance of business organizations such as Niger Mill Plc can only be sustained and maintained through a well-defined management strategy in which job analysis attempts to solve and discuss in this study. Corporate performance is a cornerstone of productivity and individual performance contributes to the accomplishment of organizational objectives (Inyang \& Akpama, 2002). The strategic aspect of organizational objectives is the corporate performance that needs to be sustained and maintained at a regular interval, and this can be effective through well-established job analysis practices or approaches during the recruitment process and training of employees in an organization. Job analysis is the prerequisite for effective and efficient management of the overall corporate performance to be achieved steadily.

The direct effect of absence job analysis during recruitment is that workers may exhibit unprofessional work practices, lack of adequate skills, and procedures that affect corporate performance due to the nature of recruitment that does not give room for merit. Also, employees under such incompetence managers/superiors will be carried along with the same nature of unproductive work behaviours and practices which will affect the corporate performance of the organization. This can be attributed to the problem of political and legal factors as well as God fatherism of man know man in the society, which is the prevailing circumstances of poor organizational corporate performance due to the absence of proactive or strategic job analysis during selection for recruitment and training of existing and prospective employees of both private and public sector organizations in Nigeria (Ele, et al, 2020).

Job analysis is one of the most important functions or activities of human resource management and can perform multi-functions such as job description, job specification, job evaluation, etc. This offer a solution for most effective work organizations or classification of work, improving ineffective processes of redesign work, planning training for introducing new employees into existing processes, or existing workers in new processes, establishes criteria assessment of employment effect, adequate and fair compensation, planning of employees welfare throughout their careers (Stoilkovska \& Serafimovic, 2017; Ele, et al 2019; Ele et al 2020). It is an integral part of human resource planning during selection for recruitment and selection for training and development needs assessment. As human resource activities grow in scope and complexity, many human resource practices such as job analysis, job description, job specification, job evaluation, recruitment and selection, compensation, performance management, career planning, training and development, and rewards need to be delegated to the human resource management department. This is because most human resource specialists do not know about the details of the jobs and their requirements. Knowledge about the jobs and their requirements must be collected through a process known as job analysis, in which information about jobs is systematically collected, evaluated, and organized. Data about each job and the person who is to perform the job need to be gathered and analyzed in an organization. Job analysis is a descriptive process of breaking down a specific job into its components by using a collection of tools and techniques to establish job requirements (Rehman, 2009). Job analysis needs to be the pillar of the recruitment and selection process of workers to perform organizational jobs to improve corporate performance in the public and private sector organizations (Ashraf, 2017). 
The person who is to do the job, the content of the jobs as well as the context at which the jobs are to be performed need to be analyzed in order to create effective corporate performance of business organizations steadily.

\section{Statement of the Problem}

Over the years, the practice of human resource management has witnessed conflict and ambiguity in determining the right person for the right job at the right time in most of the firms in the state leading to inadequate performance and low productivity. Thus, the management of business organizations must include job analysis in their human resource planning to enhance effective job description, job specification, job evaluation, job content and the persons to perform the job, who must possess the requisite knowledge, skills, and ability and attitudes. Many business organizations have no good human resource planning policy during recruitment and selection, training and development, performance management, succession planning as well as performance appraisal system. This is because job analysis practices such as job description, job specification as well as job evaluation do not exist in the business organizations either private or public for effective and efficient determination for the right persons with the accurate and acceptable knowledge, competency, abilities, skills and other job attributes to be selected during recruitment and training of existing and prospective workers to be made. Job analysis is not carefully followed in the organization, which subsequently creates conflicts of duties among employees in the organization, many employees are inducted which do not comply with this view. As human resource activities grow in scope and complexity, many human resource practices such as recruitment, selection, compensation, performance review, career planning, training, and development are needed to enhance job performance, most of the human resource specialists do not bother about the details of jobs, information about the jobs and their requirement must be collected through job analysis, with which information about the jobs is systematically collected, evaluated and organized for corporate performance to be enhanced steadily in the organization.

Ele, et al (2019) in their study also observed that inadequate or lack of a good strategic job analysis before carrying out recruitment and training process was the major cause of the poor corporate performance of public sector organizations in Cross River State. They further stated that to properly understand the dynamic nature of jobs and its complexities, managers or job analysts must gather necessary information about the jobs and the persons who are to do it from time to time for organizational performance to be enhanced steadily. The competency, knowledge, skills, abilities, and other job characteristics required for the job or jobs are not meticulously described, specifies, and evaluated in order to determine the more qualified and competent candidates to be recruited and trained for the tasks. This is characterized by the problem of lack of job analysis practices in the organization. Based on the absence of systemically carrying out job analysis results in lack of other human resource practices such as job description, job specification, job evaluation, job design, job security as well as job succession planning, making it difficult to identify the right person for the right job leading to imperfect as well as faulty recruitment and selection of employees of business enterprises in Nigeria. The problem of analyzing, describing, specifying as well as evaluating the job and its contents towards the persons, who are to perform the work has been neglected by the management during selection for recruitment as well as training of prospective and existing workers of business organizations in the society. The reduction or downside of the corporate performance of the organization as a result of lack of job analysis practices in the human resource planning processes, that is the derivative function of the human resource manager at 
the period of recruitment and training of existing and prospective workers in business organizations. The situation may result in recruiting and placing unqualified people at critical positions in an organization which will in turn affect organizational corporate performance negatively. Therefore, this study seeks to examine the correlation between job analysis and corporate performance of business organizations in Nigeria.

\section{Objectives of the Study}

The general objective was to examine the correlation existing between job analysis and corporate performance of business organizations in Nigeria. The following specific objectives were formulated to guide this research work:

1. To examine the significant relationship existing between job description and corporate performance of business organizations in Nigeria.

2. To assess the significant relationship existing between job specification and corporate performance of business organizations in Nigeria.

3. To determine the significant relationship existing between job evaluation and corporate performance of business organizations in Nigeria.

\section{THEORETICAL FRAMEWORK}

The theoretical framework of this study was anchored on a proactive job analysis model. This proactive job analysis model was developed by Ele, Umana, Inyang and Eneh (2019) in their study to describe, support and to create explicit understanding and implementation on the concept of job analysis on corporate performance of selected private sector organizations in Cross River State. The proactive job analysis model was a conceptual framework that involves the systematic examination of jobs and what it entails. The proactive job analysis model is the systematic evaluation of the tasks, duties, and responsibilities required to perform the job/task with effective evaluation of the competencies, knowledge, skill, techniques with the job attributes to do its task or work more efficiently. This model is a continuous general conceptual framework that will show the effective integration and utilization of job analysis concepts into the human resource planning policy that will help in achieving the corporate performance of organizations. This model developed here describes and predicts an improvement on the corporate performance and productivity of an organization by analyzing the jobs and the persons who are to perform it, describing the jobs, and specifying the jobs with its basic competencies, techniques, behaviours with job attributes needed to do the tasks and duties more effectively or successfully.

The implementation of this model served as a hub for an increase in the corporate performance of business organizations. The productivity that served as a measuring mechanism for effective corporate performance can be enhanced through effective and efficient utilization of resources towards effective recruitment and training processes of employees in the organizations at regular intervals. The basic relationship is that job analysis gives rise to a job description, job specification, job evaluation, and other practices or activities which aid in assessing the pertinent competencies, knowledge, skill, abilities and other job characteristics required before carrying out effective recruitment and training process of workers in organizations. Another 
relationship is that anything about competencies and abilities is essentially corporate performance and total productivity of an organization. Based on this, the implementation of this model should be done on the following steps: $i$. analyzing the needs of job analysis towards corporate performance with the scope of the project. ii. Communicating full information on the job analysis programme with the expected result to be achieved. iii. Involving the job holders that are concerned in identifying implementation problems of the job analysis. iv. Prepare action plans with constant integration of strategic or proactive job analysis exercise to be carried out in the organizations. v. Set a job analysis programme standard that will ensure the effective achievement of corporate performance at a regular interval. vi. Finally, implement the action plans if the standard set is strong and feasible with good evaluation and control mechanisms. The value of this model in the study is that the model shows a direct link and relations between job analysis and corporate performance with other intervening variables such as recruitment, training, knowledge, competencies, skills, abilities and other job characteristics required to do the jobs of business organizations more successfully.

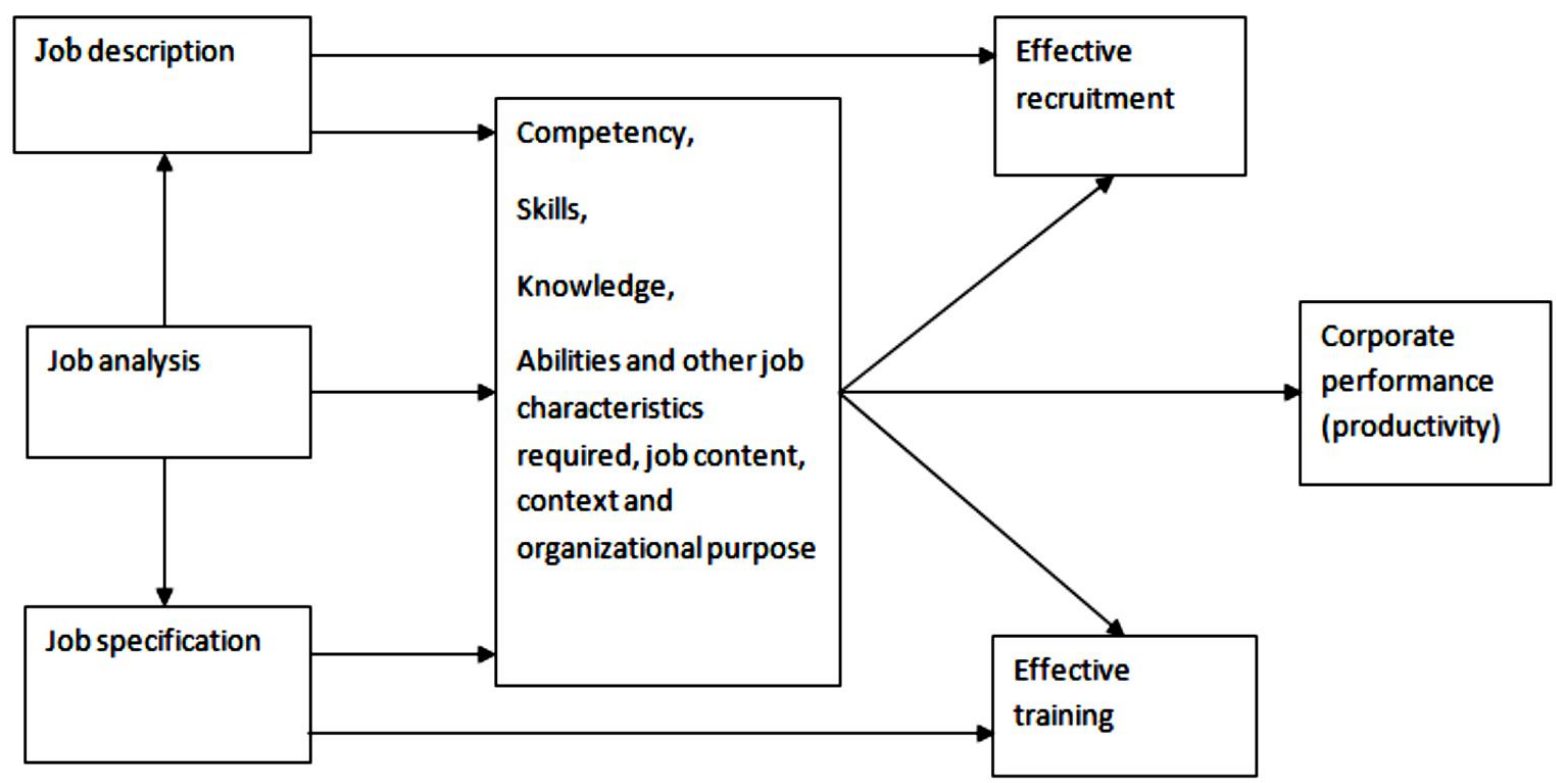

Figure 1: Proactive Job Analysis Model

Source: Ele, et al (2019).

\section{Job analysis and corporate performance}

Job analysis is the process of collecting, analyzing and setting out information about jobs in order to provide the basis for the job description, job specification, job evaluation and data for recruitment, training, job evaluation and performance management (Armstrong, 2009; 2012, Kshatriya, 2016a; 2016b). Job analysis focuses on what job holders do and achieve. Accordingly to understand the dynamic nature of jobs, managers, or job analysts should always gather necessary information about jobs to identify the task job holders undertake and the output expected to achieve. It involves developing a detailed description of the task involved in a job, determining the relationship of a given job, and ascertaining the knowledge, skills, and ability necessary for an employee to successfully perform the job (Robbins, 1996). It is the 
foundation upon which job descriptions and job specifications are written and also defines the job content. The job content describes the essential functions of the task; hence a veritable tool that enables people to price jobs and maintain absolute compliance with various employmentrelated laws. It is on this basis that; Singh (2010); Singh (2008); Siddique (2004) and Oswald (2003) viewed job analysis as a hub of virtually all human resource management practices that are necessary for the successful functioning of organizations.

\section{Job description and corporate performance}

Job description is a written statement that describes the duties of a jobholder, how the duties should be done, and why it is done. Typically, job description described the job content, environment, context, nature, and conditions of employment (Raju \& Banerjee, 2017). The focal point of job description is the job. Job description documents are the most essential features of a job, which include descriptions of the important functions of the job that details the required knowledge, skills, abilities, responsibilities, and reporting structures. The mental and physical requirements of the jobs are also included that are typically required to perform the essential functions of the job for disability act consideration (HR Guide, 2012). Al-Marwai and Subramaniam (2009) stress that job description is a document that serves very many essential functions in organizations, if written properly and constantly updated, it provides the employees with structure and design they need to carry out their jobs. Gan and Kleiner (2005) state that if job descriptions when effectively formulated and implemented, are capable of affording the organizations with the following useful objectives such as assisting in planning for the future; being able to measure future performance; enhancement of communication between employer and employees; enhancing the skills and abilities to retain qualified employees; and setting the criteria for the fair and legal discipline or terminating the workers that are unable to meet their expectations.

\section{Job specification and corporate performance}

Job specification is an organized factual statement of a specific job that tells us the minimum acceptable human qualities needed to perform a job. It is the written record of the requirement sought in an individual worker for a given job (Singh, 2010). Job specification or man specification or employee specification is the list of the essential components of a job including a summary of the work to be performed, primary duties and responsibilities, and the minimum qualifications and requirements necessary to do the crucial works of the job (Sharif \& Karim, 2017). Job specification translates the job description into human qualifications so that a job can be performed in a better manner. This is a standard of personnel that designates the quality required for acceptable performance (Inyang \& Akpama, 2002). Job specification deals with the personal aspects of the job and education or qualification background, skills, knowledge, ability, and other job characteristics required to do the job (Edien, 2015).

Thus, job specification also involves knowledge, skills, abilities, and other characteristics needed to perform the jobs. Amos, Ristow and Ristow (2004) define job specification as a statement that deals with the personal aspects of the job and the educational qualifications background, skills, knowledge, abilities, and experience to perform a job. It is prepared based on a job description. It specifies the qualities required in a job incumbent for the effective performance of the job (Singh, 2010). Job specification is a very vital tool during the employees' recruitment, training, and development process and provides business owners and managers in respect of the skills, education, work experience, managerial experience, and other 
human assets or capital which may be required from applicants to perform a particular job within the organization. However, job specification is the systematic process of specifying the type and calibre of a person that is considered fit for a particular job. In other words, job specification shows the minimum acceptable qualifications the person needs to possess to be fitted or capable in performing a particular job more effectively (Ele, et al, 2020). The focal point of a job specification is the person.

Job analysis is an organized study of jobs to recognize the visible work activities, tasks, and responsibilities related to a particular job or group of jobs (Ele et al, 2020). It is a process of looking at exactly what a job entails and identifying the particular job duties and requirements in detail reflecting the importance of these duties for a given job (Singh, 2008). The significance of job analysis in applying human resource practices cannot be ignored, as job analysis has been described as the fundamental building block upon which all later decisions in the process would rest upon. Job analysis is a process of comprehensively studying the job or task to determine what it entails (Rehman, 2009). Job analysis is one of the most important activities of human resource management and can perform multi-functions. A regular or proactive job analysis practices help to identify factors that shape the employees motivation and job satisfaction (Suthar, Chakwrawathi \& Pradhan, 2014). Job analysis is a process in which the entity as well as features of each job in an organization is investigated, sufficient information about them is collected and reported. With job analysis, its specified jobs consist of what duties and what skills as well as knowledge are required to carry out the task appropriately (Mozdabadi, 2017).

\section{Job evaluation and corporate performance}

This is the systematic evaluation and determination of the relative worth of jobs within the organization. A job is an organizational unit that consists of a group of defined activities or tasks to be performed or duties to be carried out (Armstrong, 2012). He formulated three fundamental characteristics shared by all jobs in an organization. These include the following: Job range - The number of operations a job holder performs to complete a task. Job depth The level of discretion a job holder has to decide about job activities and job outcomes. Job relationships - The interrelationship between jobholders, their managers, and co-workers. The job characteristic model is a theoretical concept concerning how the fundamental features of an employee's assigned task affect mental states and yield different workplace outcomes. Job characteristic model formulated by Hackman and Oldman (1974) was used to study how a particular job characteristic impact on job outcomes and job satisfaction.

Job evaluation is the vital foundation upon which the structure of wages and salaries rest (Ele, et al, 2020). Wages and salary structures are essential instruments developed to translate as well as reflect the organization's remuneration policy into a formal hierarchy of given grades and levels of workers (El-Hajji, 2011). Cole (2002) describes job evaluation as the name given to any activity which sets out to make a systematic comparison between jobs to assess their relative worth, to establish a rational pay structure. Job evaluation aims to assess the relative worth of a given collection of duties and responsibilities to the organization, which helps the management to maintain high levels of employees as well as employees' satisfaction (Singh, 2010). Cole (2002) further stated that job evaluation aims to reduce reliance on arbitrary methods of pay determination by introducing an element of objectivity in the ways jobs are compared with one another. Job evaluation is an open document available for checking, reviewing, and appealing its results if needed for current future development (El-Hajji, 2011). 
Similarly, the job evaluation process determined the relative worth of each job by establishing a hierarchy of positions within an organization. Job evaluations are typically completed after the job analysis and job description in collaboration with the job specification exercises are completed. The job evaluation can be either a non-quantitative method such as job classification, or a quantitative method such as a job point factor process which utilizes compensable factors to include skill, responsibility, effort, working conditions and supervision of others to determine internal worth. Job evaluation is a key for developing an internally consistent compensation system as a strategic tool for an organization to improve its corporate performance.

\section{The concept of corporate performance in an organization}

Corporate performance is defined as the process of achieving the final results of which a particular organization has been established, for the sustainability of its goals and objectives over a given period (Ele, 2014). It is the total or entire final results of all the organizational activities or practices of job or jobs performed for its efficiency and effectiveness to be maintained and achieved in an organization. The corporate performance Niger Mill Plc can only be sustained and maintained through a well-defined management strategy in which job analysis attempts to solve and discuss in this study. Corporate performance is a cornerstone of productivity and individual performance contributes to the accomplishment of organizational objectives (Inyang \& Akpama, 2002). They further defined performance as the function of ability in a multiplicative relationship with motivation, and the elements of performance consist of effectiveness, efficiency, economy, quality, productivity, and behavioural performance. It can also be seen as the way a job or task is done by an individual, a group, or an organization to improve its corporate objectives on a continuous basis.

Thus, this in turn called for corporate performance management. Corporate performance management is a special area of business intelligence which involved with the process of monitoring and managing organizational performance, according to key performance indicators such as operational costs, level of productivity, type of jobs, quality of products, return on investment (ROI), overhead, etc. Core corporate performance management processes include financial planning, operational planning, business modeling, consolidation and reporting, analysis, and monitoring of key performance indicators linked to strategy such as job analysis. However, corporate performance management also encompasses strategic planning, budgeting, forecasting, workflow, reporting, modeling, scenario planning, profitability analysis, key performance indicators monitoring, and consolidation.

Similarly, corporate performance management addresses the issues of both operational and financial performance to include the process of collecting the data and collaboratively performing analysis and reporting for executives, managers, and employees through all levels of the organizations. San and Heng (2011) stated that the high leverage firms are also more responsible to take personal actions such as restructuring assets and laying off employees when performance deteriorates. This situation will call for effective and efficient as well as wellestablished job analysis schemes or programmes to improve the corporate performance of an organization. Agwu (2012) explained the influence of hazard job analysis on organizational productivity and loss control in the Nigerian private sector organizations cannot be overemphasized, especially in the areas of setting minimum health and safety management standards of both the jobs and employees. With this, the hazard job analysis have a direct significant relationship with employees' productivity because assigned tasks can only be safe 
and conducive for the execution of the assigned duties and responsibilities, be it construction, manufacturing, and servicing. Corporate performance is contained within approaches to business process management that have three main activities such as the selection of goals, consolidation, and measurement information relevant to organizational processes towards the attainment of its goals.

The measurement of corporate performance is therefore fundamental to the success of goal setting because it provides a feedback mechanism on the current performance of an organization and highlights areas of deficiency and shows the level of discrepancy between actual and desired performance (Aluko, Odugbesan, Gbadamosi \& Osuagwu, 2014). But Than, Trenberth, and Conway (2009) argued that attempts to measure the impact of human resource management practices on organizational corporate performance are not without difficulties. The difficulties lie with problems in measuring the contributions of job analysis practices to corporate performance. Ghosh and Mukherjee (2006) stated that many performance measurement tools could be clubbed into two broad groups such as traditional measures and non-traditional measures. Traditional measures indicate the financial strengths, weaknesses, opportunities, threats and return on investment (ROI), residual income (RI), earning per share (EPS), dividend yield, price-earnings ratio, growth in sales, and market capitalization. San and Heng (2011) had used profit efficiency as a performance measure. Human resource managers and employees were evaluated by using profit efficiency, since the profit efficiency counter for the effectiveness of managers and employees to raise revenue and control cost and is close to the concept of value maximization.

Guest (1997) also suggested that both quantitative and qualitative measures of key shareholders' subjective judgments on clearly defined and identified goals and objectives of quantitative indicators, together with financial criteria are the most useful indicators of human resource management effectiveness towards corporate performance. Corporate performance can also be measured through return on investment (ROI) alone. Return on investment type of measures that are the most popular and frequently used when accounting variables are utilized to determine the corporate performance of an organization (Pazarskis, Vogiatzology, Christodoulou \& Drogalas, 2006). Corporate performance can also be measured through scale and balanced scorecard. Kuye and Oghojafor (2011) stated that corporate performance measured through scale comprises ten performance criteria. These ten corporate performance criteria consist of profit growth, scale revenue, financial strength, operating efficiency, performance stability, public image, employee morale, environmental adaptation, new ideas, and social impact on the society. For this study, corporate performance can be measured through the productivity level of the organization. Corporate performance is the pivotal point at which organizations grow and develop. Corporate performance is the function of competency, knowledge, skills, and abilities and other job characteristics required with the intervening variables of effective and efficient recruitment and training of employees in an organization. It served as the aggregate achievement or the accomplishment of an organization over a given period. The key to organizational objectives is the corporate performance that needs to be sustained and maintained at regular intervals. This will be effective through welldefined job analysis practices or approaches during the recruitment process and training of employees of both private and public sector organizations in Cross River State. 


\section{EMPIRICAL REVIEW}

Ele, et al (2019) conducted a study on the effect of job analysis on corporate performance of selected private sector organizations in Cross River State, Nigeria. The study used a survey research design, a subtype of expos facto design. The total population was 367. And 287 respondents from the then United Cement Company now Lafarge Cement Company of Nigeria and 80 respondents from HISBIKOS Nigeria Limited Calabar. The study adopted a simple random sampling technique using Taro Yamane formula for the sample size determination. The sample size was 234 respondents from the two private organizations selected for this study. 167 from the Lafarge Cement Company of Nigeria and 67 from the HISBIKOS Company of Nigeria. Data was collected using both primary and secondary sources. The data analysis technique adopted for the study was a simple linear regression model to test the hypotheses. The study revealed that proactive job analysis has a positive significant effect on the corporate performance of the private sector organizations in Cross River State. Job description and job specification also have a significant effect on the corporate performance of the selected private sector organizations. The study recommended that the management of the private sector organization should always analyze the jobs and persons who are to perform it, to sustain and maintain the corporate performance of the organizations in Cross River State. The management and human resource managers of the private sectors should at all times describe and specify the jobs and the persons who will do the jobs of the organizations in order to ensure holistic development of the companies' corporate performance in Cross River State. The study concluded that job analysis is an internal strategy or blueprint to revitalize the effectiveness and efficiency of the corporate performance of the selected private sector organizations in the state. Job analysis is the hub or the building blocks for the effective and efficient achievement of an organization's corporate performance among private firms in the area.

Syed and Mukaram (2014) investigated the role of job analysis and its impact on performance management. The study adopted face to face semi-structured interviews design and sample size of 22 Army officials of different ranks in Pakistan. The study revealed that there is a significant impact on job analysis on performance management. Based on the finding, it was concluded that Performance Management can be ensured if the Job Analysis for every position is comprehensive. Therefore, if job analysis is 'aligned' well with the organizational objectives then it would be relatively easier to ensure 'fit' between al HR functions and high corporate performance.

Ashraf (2017) conducted a study by examining public sector recruitment and selection concerning job analysis in Pakistan. Questionnaires and some brief interviews were used by adopting 5 points Likert scale. Unstructured interviews were also adopted. Primary and secondary data were collected for the study. A descriptive research design was adopted for the research work. The study revealed that the hiring process of the public sector faulty mainly because of poor job analysis. They do not make proper job description and specification and employees' tasks do not match with the given job description as well as specification, which ultimately affects the performance of the public sector organizations.

Sharif and Karim (2017) also conducted a study on the influence of job analysis programme on employees' performance: a study of selected companies in Bangladesh. The research work adopted an exploratory research design. Primary data was gathered through a structured questionnaire. Secondary sources were also adopted. The study revealed that the concept of job analysis is not a popular one in their local organizations. And that the programme helped participants to identify job duties and responsibilities properly, making them aware of their 
career development. The job analysis process must be continuously evaluated through feedback mechanisms like employee adaptation and performance. The training programme should be arranged from time to time. That a list of clear duties and responsibilities must be specified according to the position of employees. That improvement of employee skills is highly required in the companies. The organizational arrangement of skill improvement programmes is required.

Suthar, Chakravarthi and Pradhan (2014) conducted a study on impacts of job analysis on organizational performance using an inquiry on Indian Public Sector enterprises. The study used a survey questionnaire to gather data. The questionnaire was administered through email to the respondents. The population was one thousand, three hundred, and sixty-one. The sample size was four hundred and seventeen. The study adopted a quantitative research approach. Regression and correlational models were used to test the hypotheses. The study indicated that organizational performance and job analysis are positively related to each other. The study also revealed that there is a significant relationship between organizational performance and job design; organizational performance and job specification as well as organizational performance and job evaluation. The study recommended that management should conduct job analysis activities in a more scientific way that can provide specific direction to use available human power at an appropriate time and place. Management should also focus on the modern job description as well as job specification activities by considering the factors such as organizational goal-oriented functions and responsibilities, transparent job performance standards as well as free from undue influence and factors such as transparent job specification criteria (emotional specification, social specifications, behavioural specifications).

Nyasha, Katsuro, Chazuza, Makaita, Mukondiwa, Farai, Kudakwashe, Tafadzwa and Taongo (2013) conducted a study on the importance of establishing a job analysis exercise in bread manufacturing companies in Zimbabwe. Interviews and questionnaires were used in triangulation to collect data from the sample. 5 points Likert scale was adopted in the structured questionnaire. The population was 7 companies. The population was divided into strata. The sample size was 4 companies and ten percent of each group was selected using a random sampling technique. The data collected was presented using simple percentages. The study found that there is a positive correlation between well-established job analysis and employee and company performance, the impact was seen through improvements in compensation, training and development, health and safety, and recruitment and selection. The research work also found that in an era of continuous delayering and downsizing one of the most common problems derived from implementing a job analysis is employee fears. Employees see job analysis as a threat to their current jobs or pay levels or both. This was based on the fact that in the past, job analysis was used as a means of expanding jobs while reducing the total number of employees.

Mozdabadi, (2017) also conducted a study on the investigation of educational needs with job analysis approach (case study: financial and urban economy experts of Tehran Municipality). The population of the study was one hundred and forty-three. The sample size was also one hundred and forty-three, and purposive sampling was used. Data were collected using a semistructured questionnaire and interview. A mixed exploratory research design was adopted. The Lee Hee and one sample T-tests were used to test hypotheses. The study revealed that since experimental means are higher than theoretical ones, it can be stated that all obtained skills, knowledge, tool, and technology related to Tehran Municipality's urban economy experts are significantly higher than average in terms of a total of the three components of learning 
necessity, frequency, and learning difficulty and they are counted as educational need. The study recommended that in order to increase educational effectiveness, detected priorities for financial and urban economy experts should be put on the agenda by educational managers of Tehran Municipality through job analysis practices. It was also recommended that educational managers of the Tehran Municipality should try to increase the effectiveness of holding these courses.

Kshatriya (2016) also conducted a study on a job analysis and its positive impact on key recruitment and selection processes as a case study. A structured questionnaire was used. Simple random sampling was adopted. The study adopted functional job analysis methodology that was job duties, as well as job specifications, were initially identified as key knowledge, skills, abilities, and other job characteristics required for the job were extracted from critical statements using task statements and task inventory as a job classification requisite position. A performance appraisal technique was developed based on an absolute rating system using a graphical rating scale aligned to the KSAO's derived from job analysis.

Musyoka, Adoya and Ongombe (2016) carried out a study on the influence of job description on the performance of health workers in public Hospitals using Mbagathi Hospital Nairobi city country. The study adopted cross-sectional descriptive and exploratory research. The sample size of one hundred and seventy-seven respondents was determined using Taro Yamane (1967). Stratified sampling was used. Informant interviews and structured questionnaires were also used. Quantitative and qualitative data were analyzed using descriptive statistics and content analysis respectively. The statistical tool adopted to test for the hypotheses was chi-square using SPSS version 21. The quantitative data collected was coded, processed, and present inconsistencies and outliers. Results indicated that the health service managers were not aware of policies on human resource management practices such as job analysis, job description as well as job specification. The study also revealed that there is a significant association between the use of job description dimensions and performance dimensions. Work plans were lowly used and in some cases not available. The study concludes that human resource management practices were poorly implemented in the hospital. Health service managers needed basic training on job descriptions among other HRM practices including and to establish a department that will implement the practices.

\section{METHODOLOGY}

The study adopted both descriptive and correlational survey designs. The population of this research work was 400, the entire workforce of Niger Mill Plc Calabar, Cross River State. The sample size was 200 respondents determined through Taro Yamane's formula of 1964. The data was collected using both primary and secondary sources. A structured questionnaire was used using a 4-point Likert scale of strongly agreed, agreed, strongly disagreed and disagreed. The study adopted the Pearson Product Moment of Correlation Coefficient to test the hypotheses and analyzed data at $0.05 \%$ significance.

\section{Testing of hypotheses:}

1. $\mathrm{H}_{\mathrm{o}}$ : There is no significant relationship between job description and corporate performance of business organizations. 
International Journal of Entrepreneurship and Business Innovation

ISSN: 2689-9493

Volume 4, Issue 1, 2021 (pp. 61-81)

Table 1: Correlation analysis

\begin{tabular}{|c|c|c|c|c|}
\hline $\mathbf{X}$ & $\mathbf{Y}$ & $\mathbf{X Y}$ & $\mathbf{X}^{\mathbf{2}}$ & $\boldsymbol{Y}^{\mathbf{2}}$ \\
\hline 90 & 4 & 360 & 8100 & 16 \\
\hline 60 & 3 & 180 & 3600 & 9 \\
\hline 20 & 2 & 40 & 400 & 4 \\
\hline 17 & 1 & 17 & 189 & 1 \\
\hline$\sum \mathbf{x}=\mathbf{1 8 7}$ & $\sum \boldsymbol{y}=\mathbf{1 0}$ & $\sum \boldsymbol{x} \boldsymbol{y}=\mathbf{5 9 7}$ & $\sum \boldsymbol{x}=\mathbf{1 2 3 3 9 9}$ & $\sum \mathbf{y}=\mathbf{3 0}$ \\
\hline
\end{tabular}

$$
\begin{array}{ll}
r= & \frac{\left(\sum x y\right)-\left(\sum x \sum y\right)}{\sqrt{n\left(\sum x^{2}\right)-\left(\sum y\right)^{2} \mathrm{nX}\left(\sum \mathrm{x}\right)-\left(\sum y\right)^{2}}} \\
\mathrm{r}= & 4(597)-(187)(10) \\
& \sqrt{4(12,389)-(187)^{2} 4(30)-10^{2}} \\
r= & 2388-1870 \\
r= & 518 \\
r= & \frac{545}{(49556-34969) 120-100}
\end{array}
$$

Determine $t$ - calculated value

$$
\begin{aligned}
& t=\frac{8 \sqrt{\mathrm{n}-2}}{1-8^{2}} \\
& t=\frac{0.95 \sqrt{4-2}}{1-(0.95)^{2}} \\
& t=\frac{0.95 \sqrt{2}}{1-0.9025^{2}} \\
& t=\frac{1.34}{1-0,9025}=\mathbf{1 3 7}
\end{aligned}
$$

Test significance level @ D/f $=(r-2=(4-2)=2$ at 0.05 significance level was 2.92 . 
Decision Rule:

Since the calculated t-value of 137 is greater than the critical t-value of 2.92, we, therefore, rejected the null hypothesis and accept the alternative hypothesis which stated that there is a significant relationship between job description and corporate performance of business organizations.

2. $\mathrm{H}_{\mathrm{o}}$ : There is no significant relationship between job specification and corporate performance of business organizations.

Table 2: Correlation analysis for hypothesis two.

\begin{tabular}{|c|c|c|c|c|}
\hline $\mathbf{X}$ & $\mathbf{Y}$ & $\mathbf{X Y}$ & $\boldsymbol{X}^{\mathbf{2}}$ & $\mathbf{Y}^{\mathbf{2}}$ \\
\hline 82 & 4 & 328 & 6724 & 16 \\
\hline 55 & 3 & 165 & 3025 & 9 \\
\hline 30 & 2 & 60 & 900 & 4 \\
\hline 20 & 1 & 40 & 400 & 1 \\
\hline$\sum \boldsymbol{x}=\mathbf{1 8 7}$ & $\sum \boldsymbol{y}=\mathbf{1 0}$ & $\sum \boldsymbol{x y}=\mathbf{5 9 3}$ & $\sum \boldsymbol{x} \mathbf{2}=\mathbf{1 1 , 0 4 9}$ & $\sum \boldsymbol{y} \mathbf{2}=\mathbf{3 0}$ \\
\hline
\end{tabular}

$$
\begin{aligned}
& r=\frac{4(593)-(187)(10)}{\sqrt{\left(4(11049)-(187)^{2} 4(30)-10^{2}\right.}} \\
& r=\frac{42372-1870}{\sqrt{(44196-34969) 120-100}}
\end{aligned}
$$

$$
\begin{aligned}
& r=\frac{502}{430} \\
& r=1.17
\end{aligned}
$$

To calculate the $\mathrm{t}$ - value

$$
\begin{aligned}
& t=\frac{\mathrm{r} \sqrt{\mathrm{n}-2}}{1-(1.17)^{2}} \\
& t=\frac{1.17 \sqrt{4-2}}{1-(1.17)^{2}} \\
& t=\frac{1.17 \sqrt{4-2}}{0.37} \\
& t=\frac{1.65}{-0.37}=\mathbf{4 . 4 5}
\end{aligned}
$$


Decision Rule:

Since the calculated t-value of 4.45 is greater than the critical t-value of 2.92 , we, therefore, rejected the null hypothesis and accepted the alternative hypothesis which stated that there is a significant relationship between job specification and corporate performance of business organizations.

3. $\mathrm{H}_{0}$ : There is no significant relationship between job evaluation and corporate performance of business organizations.

Table 3: Correlation analysis for hypothesis three

\begin{tabular}{|c|c|c|c|c|}
\hline $\mathbf{X}$ & $\mathbf{Y}$ & $\mathbf{X Y}$ & $\mathbf{X}^{\mathbf{2}}$ & $\mathbf{Y}^{\mathbf{2}}$ \\
\hline 70 & 4 & 280 & 4900 & 16 \\
\hline 90 & 3 & 270 & 8100 & 9 \\
\hline 27 & 2 & 54 & 729 & 4 \\
\hline 0 & 1 & 0 & 0 & 1 \\
\hline$\sum \boldsymbol{x}=\mathbf{1 8 7}$ & $\sum \boldsymbol{y}=\mathbf{1 0}$ & $\sum \boldsymbol{x y}=\mathbf{6 0 4}$ & $\sum \boldsymbol{x}^{2}=\mathbf{1 3 7 2 9}$ & $\sum \boldsymbol{y}^{2}=\mathbf{3 0}$ \\
\hline
\end{tabular}

$r=\frac{4(604)-(187)(10)}{\sqrt{4(113729)-(187)^{2} 4(30)-10^{2}}}$

$r=\frac{2416-1870}{\sqrt{4(13729) 187^{2} 20}}$

$r=\frac{546}{\sqrt{19,9472}}$

$r=\frac{546}{\sqrt{398940}}$

$r=546$

$631.6=0.86$

$r=0.86$

To determine $\mathrm{t}=$ calculated value

$t=\frac{\mathrm{r} \sqrt{\mathrm{n}-2}}{1-8^{2}}$ 


$$
\begin{aligned}
t= & \frac{0.86 \sqrt{2}}{1-(0.86)^{2}} \\
t= & \frac{0.86 \sqrt{2}}{1-0.74}
\end{aligned}
$$

$\mathbf{t}=1.22$

$$
\overline{0.26}=\mathbf{4 . 6 9}
$$

Decision Rule:

Since the t-calculated value of 4.69 is greater than the $t$-critical value of 2.92 . Therefore, the null hypothesis was rejected and the alternate hypothesis which stated that there is a significant relationship between job evaluation and corporate performance of business organizations was accepted.

\section{DISCUSSION OF FINDINGS}

The study showed that there is a significant relationship between job description and corporate performance of business organizations in Nigeria. The finding is in line with the study of Nyasha et al (2013) which stated that there is a positive correlation between well-established job analysis and employee and company performance, the impact was seen through improvements in compensation, training and development, health and safety and recruitment and selection. This is also supported by the assertions of Ele et al (2019) which stated that job description, job specification as well as job evaluation has a significant effect on the corporate performance of the selected private sector organizations in Cross River State. They further stated that the business organizations need to incorporate effective job analysis as part of their strategic corporate planning policies. Ashraf (2017) also revealed that the hiring process of public sector organizations is faulty mainly because of poor job analysis scheme.

The study also revealed that there is a strong significant relationship between job specification and corporate performance of business organizations in Nigeria. This finding was supported by the finding of Suthar, Chakravarthi and Pradhan (2014) which stated that there is a significant relationship between organizational performance and job design; organizational performance and job specification as well as organizational performance and job evaluation. Musyoka, Adoya and Ongombe (2016) in their study also revealed that there is a significant association between the use of job description dimensions and performance dimensions.

The study also revealed that there is a positive and strong relationship exist between job evaluation and corporate performance of business organizations in Nigeria. Ele et al (2020) also discovered that job evaluation has a significant effect on employees' commitment of public sector organizations in Cross River State. They also revealed that there is a significant relationship between job evaluation and employees' commitment of public sector organizations in the business environment. 


\section{Implications of the study}

This study will serve as internal strategy and broad policy to be formulated during selection for recruitment and training of employees in determining the basic pertinent characteristics of a job and its requirements. The study will aid human resource managers, job analysts as well as practitioners to carry out effective job analysis before recruitment of workers to ascertain the relationship between job description, job specification, job evaluation and corporate performance of business organizations in the system. This will also help to describe the job and specify the person with the required knowledge, skills, abilities, and other job characteristics for the job in order to enhance corporate performance of business enterprises continuously.

\section{CONCLUSION}

The study investigated the correlation between job analysis and corporate performance of business organizations in Nigeria. The study concluded that well-established job analysis has a positive and significant correlation with the corporate performance of business organizations in Nigeria. It was discovered that there are significant relationships between job description, job specification, job evaluation, and corporate performance of business organizations in society. Job analysis and its basic products such as job description, job specification as well as job evaluation have effective implications on corporate performance, increase profitability, increase turnover, manpower planning, and conflict of duties, employees' productivity, growth, market share, and market value of business organizations. However, it was noted that, for the process to be effective, job analysts must inform employees who will initiate the process, how the employees will be affected. Informed consent and protect the right of participants, thereby promoting freedom and self-determination. An organization's understanding of the available and needed knowledge, skills and abilities allow them to plan for the changes to new jobs and recruit and train the right person required for achieving their organizational goals thereby sustaining them through a well-established job analysis scheme which lay a foundation of fairly and orderly pay structure and thus improves the internal relationship with employees working within the various departments and effective teamwork that decide the operational success of business organizations.

\section{RECOMMENDATIONS}

Based on the findings, the study recommended the following:

1. Management of business organizations should incorporate a well-established job analysis programme into their human resource planning during recruitment and training of existing and prospective employees to boast its overall corporate performance continuously.

2. Human resource managers should also endeavour to describe organizational jobs and the person who is to carry out the tasks with the basic knowledge, skills, competency, ability, and other job characteristics for the corporate performance to be enhanced steadily.

3. There should be a fair evaluation of jobs and equitable reward system for all employees performing similar duties irrespective of the employment status to ensure improvement on 
International Journal of Entrepreneurship and Business Innovation

ISSN: 2689-9493

Volume 4, Issue 1, 2021 (pp. 61-81)

www.abjournals.org

employees as well as corporate performance and to ensure effective and efficient established job analysis scheme to lay a foundation of fairly and orderly pay structure that need to be strictly implemented in business organizations.

4. Management of business organizations should be able to recognize the importance of job analysis in every human resource planning to anticipate their challenges and proactively plan for smooth operations and motivation of employees to boost employees' as well as corporate performance.

\section{REFERENCES}

Agwu, M. O. (2012). Impact of job hazard analysis on organizational performance in shell bonny terminal integrated project. Journal of Emerging Trends in Economics and Management Sciences, 3(2), 161-167.

Al-Marwai, S. A. \& Subramaniam. I. D. (2009). A review of the need for writing \& updating job descriptions for $21^{\text {st }}$ century organizations. European Journal of Social Sciences, 12(2), 241-251.

Aluko, M., Odugbesan, O., Gbadamosi, G. \& Osuagwu, L. (2014). Business policy and strategy ( $3^{\text {rd }}$ Ed.). Lagos: Amino Press Limited.

Amos, T., Ristow, A. \& Ristow, L. (2004). Human resource management (2nd Ed.). Lansdowne: Juta Publisher.

Armstrong, M. (2009). Handbook of human resource management practice $\left(11^{\text {th }}\right.$ Ed.). India: Replika Press Pvt Limited.

Armstrong, M. (2012). Handbook of human resource management practice (12 ${ }^{\text {th }}$ Ed.). United Kingdom: Ashford Colour Press.

Ashraf, J. (2017). Examining the public sector recruitment and selection, in relation to job analysis in Pakistan. Cogent Social Sciences, 3, 1-11.

Cole, A. (2002). Personnel and human resource management (5Ed.). London: Book Power/ELST Imprint.

Edien, A. G. A. (2015). Effects of job analysis on personnel innovation. International Journal of Business and Management Invention, 4(10), 9-18.

Ele, A. A. (2014). Impact of job analysis on corporate performance: A study of selected private sector organizations in Cross River State, Nigeria. Unpublished M.Sc. Thesis in the Department of Business Management, University of Calabar, Calabar.

Ele, A. A., Makama, L. L. \& Okongo, N. J. (2020). Imperative implications of job analysis on employees' commitment of public sector organizations in Cross River State, Nigeria. International Journal of Business and Management Review, 8(1), 49-68.

Ele, A. A., Umana, E. A., Inyang, B. J. \& Eneh, S. I. (2019). Effect of job analysis on corporate performance of the selected private sector organizations in Cross River State, Nigeria. IOSR Journal of Business and Management, 21(11), 41-52.

El-Hajji, A. M. (2011). Some recent trends in writing a job description for the purpose of job evaluation: A reflective view. American International Journal of Contemporary Research, 1(3), 6-14.

Ghosh, S. \& Mukherjee, S. (2006). Measurement of corporate performance through balanced scorecard: An overview. International Journal of Commerce, 11(1), 60-70.

Guest, D. (1997). Human resource management and performance: A review and research agenda. International Journal of Human Resource Management, 8(3), 263-276. 
International Journal of Entrepreneurship and Business Innovation

ISSN: 2689-9493

Volume 4, Issue 1, 2021 (pp. 61-81)

www.abjournals.org

Inyang, B. J. \& Akpama, A. M. (2002). Personnel management practice in Nigeria. Calabar: Merb Business Publisher.

Kshatriya, S. (2016). Job analysis and its positive impact on key recruitment and selection processes: A case study. Al Dar Research Journal of Sustainability, 1(1), 47-68.

Kshatriya, S. (2016). Linkage of job analysis to performance management: A case study. International Journal of Management Information Technology and Engineering, 6(9), 202-222.

Kuye, O. L. \& Oghojafor, B. E. A. (2011). Strategic control and corporate performance in the manufacturing industry: Evidence from Nigeria. European Journal of Social Sciences, 22(2), 177-187.

Mozdabadi, S. M. T. (2017). Investigation of educational needs with job analysis approach (Case study: Financial and urban economy experts of Tehran Municipality). The Scientific Research Quarterly Journal of Urban Economics and Management, 4(3), 127-146.

Musyoka, F. N., Adoya, M. A. \& Ongombe, M. O. (2016). Influence of job description on the performance of health workers in public hospitals: A case of Mbagathi Hospital Nairobi city country. Science Journal of Public health, 4(2), 88-93.

Nyasha, M., Katsuro, P., Chazuza, T., Makaita, M. M., Mukondiwa, T., Farai, M., Kudakwashe, N. N., Tafadzwa, U. \& Taongo, M. (2013). Importance of establishing a job analysis exercise in an organization: A case study of bread manufacturing companies in Zimbabwe. Austrian Journal of Business and Management Research, 2(11), 35-42.

Oswald, F. L. (2003). Job analysis: Methods, research, and applications for human resource management in the new millennium. Journal of Personnel Psychology, 56(3), 798-802.

Pazarskis, M., Vogiatzology, M., Christodoulou, P. \& Drogalas, G. (2006). Exploring the improvement of corporate performance after acquisitions and mergers, the case of Greece. International Research Journal of Finance and Economics, 6, 184-192.

Raju, K. K. \& Banerjee, S. (2017). A study on job description and its effect on employee performance. Case of some selected manufacturing organizations in the city of Pune, India. International Journal of Latest Technology in Engineering, Management \& Applied Science (IJLTEMAS), 6(2) 1-10.

Rehman, S. M. (2009). Impact of job analysis on job performance: A case study of public sector organizations of Pakistan. Ph.D. Thesis of National University of Modern Languages Islamabad. Retrieved from www.eprints.hec.gov.pk/6512/

Robbins, S. P. (1996). Organizational behaviour: Concepts, controversies, applications (7Ed.). Englewood Cliffs-New Jersey: Prentice-Hall.

San, O. T. \& Heng, B. T. (2011). Capital structure and corporate performance of the Malaysian construction sector. International Journal of Humanities and Social Science, 1(2), 28-36.

Sharif, A. \& Karim, M. M. (2017). Influence of job analysis program on employees: A study of selected companies in Bangladesh. International Journal of Scientific \& Engineering Research, 8(5), 1221-1225.

Siddique, C. M. (2004). Job analysis: Strategic human resource management practice. International Journal of Human Resource Management, 15(1), 219-244.

Singh, P. S. (2008). Job analysis for a changing workplace. Journal of Applied Psychology, $88(4), 635-646$.

Singh, P. S. (2010). Human resource management ( $1^{\text {st }}$ Ed.). India: Virender Kumar Arya Publisher. 
Stoilkovska, A. \& Serafimovic, G. (2017). Job analysis as an important human resource management function. International Refereed Scientific Journal Vision, 2(1), 113-124.

Stybel, L. J. (2010). Managing the inner contradictions of job descriptions: A technique for use in recruitment. The Psychologist-Manager Journal, 13(1), 105-110.

Suthar, B. K., Chakravarthi, T. L. \& Pradhan, S. (2014). Impacts of job analysis on organizational performance: An inquiry on Indian public sector enterprises. ELSEVIER Procedia Economics and Finance, 11, 166-181.

Syed, F. \& Mukaram, N. (2014). The role of job analysis and its impact on performance Management. International Journal of Academic Research in Business and Social Sciences, 3(10), 250-268

Than, S. S., Trenberth, L. \& Conway, N. (2009). The impact of management development system on firm performance: Comparing Asia with Europe. New Zealand Journal of Human Resource Management - Special Issue, 131-144. 